\title{
Agrp Neurons Mediate Sirt1's Action on the Melanocortin System and Energy Balance: Roles for Sirt1 in Neuronal Firing and Synaptic Plasticity
}

\author{
Marcelo 0. Dietrich, ${ }^{1,4}$ Catiele Antunes, ${ }^{1,4}$ Gan Geliang, ${ }^{2}$ Zhong-Wu Liu, ${ }^{2}$ Erzsebet Borok, ${ }^{1}$ Yongzhan Nie, ${ }^{1}$ \\ Allison W. Xu, ${ }^{5}$ Diogo O. Souza, ${ }^{4}$ Qian Gao, ${ }^{1}$ Sabrina Diano, ${ }^{2}$ Xiao-Bing Gao, ${ }^{2}$ and Tamas L. Horvath ${ }^{1,2,3}$ \\ ${ }^{1}$ Program on Cell and Neurobiology of Energy Metabolism, Section of Comparative Medicine and Departments of ${ }^{2} \mathrm{Obstetrics}$, Gynecology, and \\ Reproductive Sciences and ${ }^{3}$ Neurobiology, Yale University School of Medicine, New Haven, Connecticut 06520, ${ }^{4}$ Department of Biochemistry, Universidade \\ Federal do Rio Grande do Sul, Porto Alegre RS 90035, Brazil, and 5Diabetes Center, University of California, San Francisco, San Francisco, California 94143
}

Sirt1 has been associated with various effects of calorie restriction, including an increase in lifespan. Here we show in mice that a central regulatory component in energy metabolism, the hypothalamic melanocortin system, is affected by Sirt1, which promotes the activity and connectivity of this system resulting in negative energy balance. In adult mice, the pharmacological inhibition of brain Sirtl activity decreased Agrp neuronal activity and the inhibitory tone on the anorexigenic POMC neurons, as measured by the number of synaptic inputs to these neurons. When a Sirt1 inhibitor (EX-527) was injected either peripherally (i.p., $10 \mathrm{mg} / \mathrm{kg}$ ) or directly into the brain (i.c.v., $1.5 \mathrm{nmol} / \mathrm{mouse}$ ), it decreased both food intake during the dark cycle and ghrelin-induced food intake. This effect on feeding is mediated by upstream melanocortin receptors, because the MC4R antagonist, SHU9119, reversed Sirt1's effect on food intake. This action of Sirt1 required an appropriate shift in the mitochondrial redox state: in the absence of such an adaptation enabled by the mitochondrial protein, UCP2, Sirt1-induced cellular and behavioral responses were impaired. In accordance with the pharmacological results, the selective knock-out of Sirt1 in hypothalamic Agrp neurons through the use of Cre-Lox technology decreased electric responses of Agrp neurons to ghrelin and decreased food intake, leading to decreased lean mass, fat mass, and body weight. The present data indicate that Sirt1 has a central mode of action by acting on the NPY/Agrp neurons to affect body metabolism.

\section{Introduction}

Sirtuins are NAD+-dependent class III deacetylases that are highly conserved across species (Brachmann et al., 1995). Sirt1, the mammalian ortholog of Sir2, has been implicated in caloricrestriction-induced longevity (Kaeberlein et al., 1999; Lin et al., 2000; Tissenbaum and Guarente, 2001; Cohen et al., 2004; Rogina and Helfand, 2004; Chen et al., 2005). Nutrient deprivation upregulates Sirt1 in several tissues (Cohen et al., 2004; Ramadori et al., 2008), which is crucial for the metabolic shift that occurs during negative energy balance (Liu et al., 2008), a metabolic state in which the energy expenditure is higher than the energy intake.

Evidence suggests that the effects of sirtuins mimic the beneficial effects of calorie restriction, the only known physiological

Received May 1, 2010; revised July 15, 2010; accepted July 16, 2010.

M.O.D. and C.A. were partially supported by Conselho Nacional de Desenvolvimento Científico e Tecnológico (Brazil). T.L.H. and X.-B.G. were supported by grants from the National Institutes of Health (NIH) and American Diabetes Association (ADA). S.D. was supported by grants from the NIH, ADA, and Juvenile Diabetes Research Foundation. D.0.S. was supported by grants from Financiadora de Estudos e Projetos/Ministério da Ciência e Tecnologia and Iniciação Científica for Excitotoxicity and Neuroprotection. Q.G. was supported by a grant from the ADA. We are thankful to Marya Shanabrough for the comments and revisions on the manuscript. T.L.H. dedicates this paper to the memory of his grandfather, Dr. Ferene Ven (1912-2010), who devoted his life to his family and his patients in Hungary during war, oppression, and peace.

Correspondence should be addressed to Tamas L. Horvath, 375 Congress Avenue, LSOG 117, New Haven, CT 06520. E-mail: tamas.horvath@yale.edu.

DOI:10.1523/JNEUROSCI.2234-10.2010

Copyright $\odot 2010$ the authors $\quad$ 0270-6474/10/3011815-11\$15.00/0 intervention that promotes a longer, healthier lifespan across species (Kaeberlein et al., 1999; Lin et al., 2000; Tissenbaum and Guarente, 2001; Cohen et al., 2004; Rogina and Helfand, 2004; Chen et al., 2005; Chen and Guarente, 2007). The similarities between the action of sirtuins and calorie restriction raise the possibility that sirtuins may exert their effect, at least in part, by affecting brain circuits controlling negative energy balance, the metabolic state promoted by calorie restriction.

The central melanocortin system located in the arcuate nucleus (ARC) of the hypothalamus is involved in the regulation of energy metabolism (Cone, 2006). This system consists of two components: a neuronal population that produces neuropeptide Y (NPY), agouti-related protein (Agrp), and GABA, which promotes feeding in response to hunger and thus, negative energy balance; and a neighboring cell population producing proopiomelanocortin (POMC)-derived peptides, such as $\alpha$-melanocyte-stimulating hormone ( $\alpha$-MSH) and cocaine-andamphetamine-regulated transcript (CART) peptides, which promotes satiety and thus, positive energy balance. The interaction between these two sets of neurons is such that the NPY/Agrp neurons maintain a unidirectional tonic inhibition onto the POMC neurons (Horvath et al., 1992; Cowley et al., 2001; Pinto et al., 2004). The selective elimination of the orexigenic NPY/Agrp neurons in adult mice leads to cessation of feeding (Gropp et al., 2005) and death (Luquet et al., 2005; Wu et al., 2009). The interaction and connectivity of these hypothalamic circuits are not 
static; they exhibit substantial plasticity depending on the metabolic environment (Pinto et al., 2004; Gao et al., 2007), a process that relies on the redox state and plasticity of the mitochondria (Andrews et al., 2008).

Sirtl is expressed in the hypothalamus (Ramadori et al., 2008), its function is redox dependent (Prozorovski et al., 2008), and it is induced by negative energy balance (Cohen et al., 2004; Chen et al., 2008; Ramadori et al., 2008). Therefore, Sirt1 may play a role in cellular adaptations in response to negative energy balance. In the brain, the central melanocortin system regulates energy metabolism (Cone, 2006) and its adaptive responses to a changing metabolic environment include synaptic (Pinto et al., 2004; Gao et al., 2007; Andrews et al., 2008) and mitochondrial (Coppola et al., 2007; Andrews et al., 2008) plasticity. Here, we examined whether Sirt1 activity may play a role in these cellular adaptations.

\section{Materials and Methods}

Animals. Adult male mice were used in the pharmacological studies. The mice were at least 2 months old when single housed for food intake measurements and they were allowed to habituate to single housing for at least 2 weeks before the start of experiments. All animals were kept in temperature and humidity controlled rooms, in a $12 / 12 \mathrm{~h}$ light/dark cycle, with lights on from 7:00 A.M. to 7:00 P.M. Food and water were provided ad libitum, unless otherwise stated. The total number of animals used for these experiments is 247 .

Transgenic mice. UCP2 knock-out mice were generated as reported previously (Zhang et al., 2001) and the original breeding pairs were kindly provided by Dr. Bradford Lowell (Beth Israel Deaconess Medical Center and Harvard Medical School, Boston, MA), and have been maintained in our laboratory on a mixed background. This transgenic mouse is available from The Jackson Laboratory: B6.129-Ucp2tm1Lowl/J, stock number 005934). POMC-GFP and NPY-GFP mice were provided by Dr. J. Friedman (Rockefeller University, New York, NY) and have been maintained on a B6 background for $>10$ generations. Both the NPY-GFP [B6.Cg-Tg(NPY-MAPT/Sapphire)1Rck/J; stock number 008321] and the POMC-GFP [B6.Cg-Tg(Pomc-MAPT/GFP*)1Rck/J, stock number 008322] mice are available from The Jackson Laboratory. Sirt ${ }^{\text {loxP } / l o x P}$ mice were purchased from The Jackson Laboratory (B6; 129-Sirt $1^{\text {tm lgu }} / \mathrm{J}$; stock number 008041) and have been generated as published (Li et al., 2007). Tg.AgrpCre mice have been maintained in our colony on a mixed background (Kaelin et al., 2004; Xu et al., 2005a,b) and backcrossed to the reporter line Rosa26 mice [B6.129S4-Gt(ROSA)26Sor ${ }^{\text {tm } 1 S o r}$ - originally from The Jackson Laboratory]. All procedures were approved by local committees (Institutional Animal Care and Use Committee from Yale University and from Universidade Federal do Rio Grande do Sul).

Generation of Agrp-Sirt1 KO mice. To evaluate the role of Sirt1 in relation to NPY/Agrp neurons and the regulation of metabolism, we used Cre/Lox technology to knockdown the catalytic domain of Sirt1 in this population of cells. Transgenic mice expressing Cre recombinase selectively in the Agrp-expressing cells (Kaelin et al., 2004; Xu et al., 2005a,b) were bred with mice harboring a targeted mutant Sirt1 allele (Sirt ${ }^{\text {loxP }}$ ) (Li et al., 2007). The Sirt ${ }^{\text {loxP/loxP }}$ mice contain loxP sequences flanking the exon 4 of the Sirtl gene, which encodes 51 aa of the Sirtl catalytic domain. When bred with the AgrpCre ${ }^{+}$mice, the deleted Sirtl allele $\left(S i r t 1^{\Delta \mathrm{ex} 4}\right)$ transcribes a mutant protein that has no apparent residual Sirtl activity or dominant negative effects (Cheng et al., 2003; Li et al., 2007). Thus, we used this knockdown model of Sirt1 in the NPY/Agrp neurons to further elucidate the role of this sirtuin in body metabolism. We describe our data by referring to "control" and "Agrp-Sirt1 KO" mice.

To generate Agrp-specific Sirt1 KO mice, we used established breeding strategies similar for this Cre line (Xu et al., 2005a,b; see supplemental Fig. 7, available at www.jneurosci.org as supplemental material). To evaluate the specificity and efficacy of the Cre deletion, we used Rosa26 reporter mice (Soriano, 1999). We found rates of ectopic expression of Cre $(\sim 30-40 \%)$ similar to those reported previously (Xu et al., 2005a,b).
This Cre line has been validated in several previous reports ( $\mathrm{Xu}$ et al., 2005a,b; Kitamura et al., 2006; Könner et al., 2007).

By breeding Tg.AgrpCre ${ }^{+}$-Sirt $1^{\operatorname{lox} P /+}$ with Sirt $1^{\operatorname{lox} P / \operatorname{lox} P}$ mice, we were able to get Mendelian ratios of Cre and floxed alleles in the offspring. In the first characterization period, we found that the Cre deleted heterozygote mice for the Sirt ${ }^{\operatorname{lox} P}$ allele (Tg.AgrpCre ${ }^{+}-$Sirt $1^{\Delta \text { ex4/+}}$ ) exhibited an intermediate phenotype compared to control littermates and homozygote $\mathrm{KO}$ mice (Tg.AgrpCre ${ }^{+}-\mathrm{Sirt1}^{\Delta \mathrm{ex} 4 / \Delta \mathrm{ex} 4}$ ). The mice carrying the AgrpCre allele and their Cre-negative controls showed no differences in phenotype (data not shown), in accordance with previous reports (Xu et al., 2005a,b; Pierce and Xu, 2010). Thus, we pooled the Cre-negative mice (control group) and Cre-positive mice without the floxed allele.

Metabolic chamber recordings. Adult female mice $(n=11)$ were acclimated in metabolic chambers (TSE Systems-Core Metabolic Phenotyping Center, Yale University) for $4 \mathrm{~d}$ before the start of the recordings. Mice were continuously recorded for $3 \mathrm{~d}$ with the following measurements being taken every 30 min: water intake, food intake, ambulatory activity (in $\mathrm{X}$ and $\mathrm{Z}$ axes), and gas exchange $\left(\mathrm{O}_{2}\right.$ and $\left.\mathrm{CO}_{2}\right)$ (using the TSE LabMaster system). $\mathrm{VO}_{2}, \mathrm{VCO}_{2}$, and energy expenditure were calculated according to the manufacturer's guidelines (PhenoMaster Software, TSE Systems). The respiratory exchange rate was estimated by calculating the ratio of $\mathrm{VCO}_{2} / \mathrm{VO}_{2}$. Values were adjusted by body weight to the power of $0.75\left(\mathrm{~kg}^{-0.75}\right)$ where mentioned.

For the fasting response study, the same mice used above were acclimated to the cages for $4 \mathrm{~d}$ and then food was removed from the cages $2 \mathrm{~h}$ before the dark cycle. The metabolic parameters (cited above) were recorded during zeitgeber time (ZT) $12-18$ and the data were analyzed as above.

Body composition. Adult male $(n=13)$ and female $(n=11)$ control and Agrp-Sirt1 KO mice were scanned in a Lunar PIXImus Densitometer (GE Medical Systems) in the Department of Orthopedics at Yale University, and their body composition was estimated based on manufacturer's algorithms. All mice were sedated with a mixture of ketamine and xylazine before scanning.

Food intake measurements. For nocturnal food intake, animals were weighed and injected 30-60 min before the beginning of the dark cycle (ZT 11). Food pellets were weighed and added to the mouse cage at the start of the dark cycle (ZT 12). Food intake was measured after $4 \mathrm{~h}$ (ZT 16) and overnight (ZT 0). For ghrelin-induced feeding, mice received the first treatment (i.p., $1 \mu \mathrm{g} / \mathrm{g}$ of body weight) in the middle of the light cycle (ZT 6) and the second injection 30-60 min later (ZT 7). Food pellets were then weighed and added to the mouse cages $30 \mathrm{~min}$ after the last injection, and food intake was measured every hour for $4 \mathrm{~h}$. Before the start of the experiments, the home cages were changed to avoid biased results due to mice eating food that may have been deposited in the bedding of the cages. After the experiments, all cages were inspected for food spillage, and those mice in cages with visible food deposits in the bedding were excluded from the studies. However, it is important to note that very few mice had to be excluded from our experiments due to food spillage (2 mice out of 173). We observed that giving mice fewer food pellets (but enough for ad libitum feeding) in the cage during the single housing acclimatization period resulted in considerably less food spillage.

For the experiments in which food intake, water intake, and locomotor activity were followed concomitantly, mice were allowed to acclimate to the metabolic chambers (TSE Systems) for $4 \mathrm{~d}$ before the start of the recording. Mice were recorded for $24 \mathrm{~h}$ before and after EX-527 treatment. For the dose-response and SHU9119 studies, mice were recorded overnight (bin size for all experiments $=30 \mathrm{~min}$ ). All measurements were taken automatically through the use of the LabMaster Phenotyping system (TSE Systems).

Intracerebroventricular cannulation. Mice were injected with buprenorphine $(0.05 \mathrm{mg} / \mathrm{kg}$, s.c.) $30 \mathrm{~min}$ before surgery. They were anesthetized using a mixture of ketamine $(100 \mathrm{mg} / \mathrm{kg})$ and xylazine $(10 \mathrm{mg} /$ $\mathrm{kg}$ ) given intraperitoneally. Mice were placed in a stereotaxic apparatus (Kopf Instruments), and a small cut was made in the skin above the skull. A drop of a pharmaceutical $\mathrm{H}_{2} \mathrm{O}_{2}$ solution was placed on the skull for better visualization of bregma and lambda. A small hole was carefully drilled into the skull, enough to insert the cannula (26 ga, Plastics One). 
Coordinates were $+1.0 \mathrm{~mm}$ (lateral), $-0.5 \mathrm{~mm}$ (posterior), $+2.0 \mathrm{~mm}$ (caudal) from bregma (Paxinos and Franklin, 2001). Animals were kept warm and proper postsurgical care was taken.

Drug injections. For intraperitoneal injections, $10 \mathrm{ml} / \mathrm{kg}$ solution was injected, and for intracerebroventricular injections, $3 \mu \mathrm{l}$ was slowly injected into the lateral ventricles, using a 5-10 $\mu$ l Hamilton syringe (Hamilton) connected to a calibrated polyethylene tube. After the experiments, cannula placement was confirmed by injecting methylene blue. Of the 219 mice, 6 were excluded due to misplaced cannulas.

Several compounds have been shown to modulate Sirtl activity. More recently, synthetic compounds acting directly on Sirt1 have also been developed with higher affinity and specificity (Napper et al., 2005). One of these compounds, EX-527 (Napper et al., 2005) has been extensively studied (Napper et al., 2005; Solomon et al., 2006; Nie et al., 2009; Pacholec et al., 2010); EX-527 is a low-molecular-weight, cell-permeable, biostable molecule that binds directly to the Sirtl catalytic domain and inhibits its activity (Huhtiniemi et al., 2006; Pacholec et al., 2010). Thus, we have chosen to use this molecule to pharmacologically inhibit Sirt1 activity. EX-527 (Tocris Bioscience) was freshly prepared, dissolved in dimethylsulfoxide (DMSO) to a stock concentration of $50 \mathrm{~mm}$, and then diluted in ultrapure water to a final concentration of between 0.3 and 3.0 $\mathrm{nmol} / 3 \mu \mathrm{l}$ (with the DMSO final concentration between 1 and $2 \%$ ); appropriate vehicles were used as controls. Mice were injected with $3 \mu \mathrm{l}$ (i.c.v.) of drug solution or vehicle. For the SHU9119 experiment, SHU9119 (Sigma-Aldrich-140 pmol/mouse) was injected concomitantly with EX-527 (1.5 nmol/mouse). All solutions were sterile filtered through $0.2 \mu \mathrm{m}$ syringe filters (Pall).

Immunohistochemistry for GFP and c-fos. GFP and c-fos double immunohistochemistry was performed by sequential addition of primary antibodies. Coronal brain sections $(50 \mu \mathrm{m})$ were washed several times in phosphate buffer ( $\mathrm{PB}, 0.1 \mathrm{M})$, $\mathrm{pH} 7.4$, reacted with $1 \% \mathrm{H}_{2} \mathrm{O}_{2}$ in $0.1 \mathrm{M} \mathrm{PB}$ solution for 15 min to block endogenous peroxidase activity, and preincubated with Triton X-100 for $30 \mathrm{~min}$. Sections were then washed several times and blocked with $2 \%$ normal goat serum and incubated with chicken anti-GFP $\left(1: 8000,4^{\circ} \mathrm{C}, 48 \mathrm{~h}\right.$; Abcam $)$. After, sections were extensively washed and incubated with biotinylated donkey anti-chicken secondary antibody [1:500, $2.5 \mathrm{~h}$ at room temperature (RT), Jackson ImmunoResearch Laboratories]. After washing, sections were incubated in $\mathrm{ABC}$ and washed, and immunoreactivity was visualized using diaminobenzidine $(\mathrm{DAB})$. Sections were then washed extensively and incubated with rabbit anti-c-fos (1:20,000 at $4^{\circ} \mathrm{C}$ for $48 \mathrm{~h}$; Oncogene). Following several washes, sections were incubated with biotinylated goat anti-rabbit secondary antibody (1:500, 2.5 h, RT, Vector Laboratories), then washed again and incubated in avidin-biotin complex (Vectastain, ABC Elite kit, Vector Laboratories) for $90 \mathrm{~min}$ at RT. Immunoreactivity for $\mathrm{c}-\mathrm{fos}$ was visualized with nickel diaminobenzidine (Ni-DAB) reaction for $5 \mathrm{~min}$ or until desired staining. This approach visualized nuclear $\mathrm{c}$-fos as a black precipitate and NPY-GFP neurons as brown cytoplasmic staining, allowing for easy identification and quantification of NPY/c-fos cells. Sections were then mounted and coverslipped with Depex mounting medium. Unbiased stereology methods were used to quantify NPY/cfos-immunoreactive cells in the ARC. Cells were visualized by a Zeiss microscope and relayed via a MicroFibre digital camera to a computer, where they were counted using the optical fractionator with the StereoInvestigator software (MicroBrightField). Two sections, $200 \mu \mathrm{m}$ apart $(-1.50 \mathrm{~mm}$ to $-1.70 \mathrm{~mm}$ from bregma), were collected through the ARC and all NPY, c-fos, and NPY/c-fos cells were counted, using a $63 \times$ oil objective, in grids randomly positioned by the software in the outlined counting area through all optical planes, thus creating a three-dimensional counting area. Cells were only counted if they touched the inclusion border or did not touch the exclusion border of the sampling grid. Data are reported as the relative number of doublestained cells (c-fos positive and GFP positive) divided by the total number of GFP-positive cells.

Immunohistochemistry for POMC. In these studies, adult male mice on a mixed background (B6.129) were used. Mice were injected with EX-527 or vehicle before the dark cycle (ZT 11) and were perfused at ZT 17. Mice were deeply anesthetized and the left ventricle of the heart was rapidly cannulated and flushed with $0.9 \%$ saline containing heparin followed by freshly prepared fixative (paraformaldehyde $4 \%$, gluteraldehyde $0.1 \%$, picric acid 15\%, in PB $0.1 \mathrm{~m}, \mathrm{pH} 7.4$ ). Usually, the time between opening the thoracic cavity and the heart cannulation was $<30 \mathrm{~s}$. Brains were then dissected out and postfixed overnight in fixative without gluteraldehyde. After vigorous washing in cold $\mathrm{PB}(0.1 \mathrm{M})$, vibratome sections were cut $(40-60 \mu \mathrm{m})$ containing the ARC of the hypothalamus. Sections were washed in PB several times, cryoprotected, and subsequently frozen and thawed three times in liquid nitrogen. After extensive washing in $\mathrm{PB}$, slices were incubated with $\mathrm{H}_{2} \mathrm{O}_{2}(1 \%, 20$ min, RT, shaking) to block endogenous peroxidase activity. After washing again with $\mathrm{PB}$, sections were incubated with primary antibody (anti-POMC, $1: 4000,48 \mathrm{~h}, 4^{\circ} \mathrm{C}$, gentle shaking). Sections were extensively washed, incubated with secondary antibody ( $2 \mathrm{~h}, \mathrm{RT}$ ), washed again, put in $\mathrm{ABC}$, and developed with $\mathrm{DAB}$. Sections were then osmicated ( $15 \mathrm{~min}$ in $1 \%$ osmium tetroxide in PB) and dehydrated in increasing ethanol concentrations. During the dehydration, $1 \%$ uranyl acetate was added to the $70 \%$ ethanol to enhance ultrastructural membrane contrast. Dehydration was followed by flat embedding in Durcupan. Ultrathin sections were cut on a Leica ultra microtome, collected on Formvar-coated single-slot grids, and analyzed with a Tecnai 12 Biotwin (FEI) electron microscope. All investigators were blinded to the experimental groups during the entire procedure.

Quantitative synaptology and mitochondria counting. The analysis of synapse number was performed in an unbiased manner (Cowley et al., 2001; Gao et al., 2007) and is presented as number of synapses per 100 $\mu \mathrm{m}$ of cell membrane. For mitochondrial counting, random sections containing POMC cells with a visible nucleus were analyzed. Mitochondria were counted in the POMC cells and the trans-sectional area of each mitochondrion was measured. The data are expressed as number of mitochondria per cell area (in square micrometers) or total mitochondria trans-sectional area (in square micrometers) per cell area (in square micrometers). Therefore, the ratio of the total mitochondria area divided by the cell area can give a very good estimation of the percentage of the cell body occupied by mitochondria. Additionally, the trans-sectional area of each mitochondrion counted and their circularity were measured as indexes of mitochondria morphology. Macnification 1.6 and MatLab R2009a were used for analysis.

Electrophysiology. Four-week-old POMC-GFP male mice were kept in a room with an inverted light/dark cycle (lights on from 8:00 P.M. to 8:00 A.M.) for at least 2 weeks before electrophysiological recordings. Mice were killed at the beginning of the dark cycle, and the ARC was sliced into $250 \mu \mathrm{m}$ slices (2/mouse), containing the POMC-GFP cells. Slices were then incubated with vehicle or EX-527 at $35^{\circ} \mathrm{C}$ for $4 \mathrm{~h}$ before cells were transferred to recording chambers. For NPY-GFP cell recording, 4- to 7-week-old male NPY-GFP mice were killed at the beginning of the light phase and the ARC was cut into $250 \mu \mathrm{m}$ slices (2/mouse), containing NPY-GFP cells. After stabilization in ACSF, slices were transferred to the recording chamber and perfused with ACSF plus vehicle or EX-527. For ghrelin-induced cell activation, the basal firing rate was recorded for at least $10 \mathrm{~min}$. The slice was then incubated with ghrelin $(0.05 \mu \mathrm{M})$ for 8-10 min, followed by a washout (with no ghrelin). Either vehicle or EX-527 $(50 \mu \mathrm{M})$ was kept in the bath solution during the entire recording period.

Six-week-old Agrp-Sirt1 KO-GFP and control-GFP mice were fasted overnight and killed at the beginning of the light cycle. Whole-cell current-clamp recording was performed using low-resistance (3-4 M $\Omega$ ) pipettes. The composition of the pipette solution was as follows (in $\mathrm{mM}$ ): K-gluconate $125, \mathrm{MgCl}_{2}$ 2, HEPES 10, EGTA 1.1, Mg-ATP 4, $\mathrm{Na}_{2}$ phosphocreatin 10 , and $\mathrm{Na}_{2}$-GTP $0.5, \mathrm{pH} 7.3$ with $\mathrm{KOH}$. The composition of the bath solution was as follows (in mM): $\mathrm{NaCl} 124, \mathrm{KCl} 3, \mathrm{CaCl}_{2}$ 2, $\mathrm{MgCl}_{2} 2, \mathrm{NaH}_{2} \mathrm{PO}_{4}$ 1.23, glucose 2.5, sucrose 7.5, and $\mathrm{NaHCO}_{3} 26$. After a gigaohm seal and whole-cell access were achieved, membrane potential and action potentials were recorded under current clamp at 0 pA. Ghrelin $(0.05 \mu \mathrm{M})$ was applied to the bath solution and perfused to the slice. All data were sampled at $3-10 \mathrm{kHz}$ and filtered at $1-3 \mathrm{kHz}$ with an Apple Macintosh computer using Axograph 4.9 (Molecular Devices). Electrophysiological data were analyzed with Axograph 4.9 and plotted with KaleidaGraph 3.6 (Synergy Software) and Igor Pro 5.04 (WaveMetrics). Membrane potential and action potentials were detected and mea- 
sured with an algorithm in Axograph 4.9. The frequency of action potential and membrane potential were expressed as mean \pm SEM.

Statistical analysis. We used software packages to analyze the data (Matlab R2009a and PASW Statistics 18.0) and plot the figures. First, we tested the homogeneity of variance across the different experimental conditions using Levene's or Bartlett's test.

When the $p$ value was $>0.05$ in these tests, homogeneity was assumed, and a parametric ANOVA test was used. The Student's $t$ test was used to compare two groups. One-, two-, or three-way ANOVA was used as the other tests unless stated otherwise. Multiple comparisons were performed as described below. For repeated measures analysis we used a mixedmodel ANOVA with time as a "within-subject repeated-measures" factor and treatments/genotype as a "between-subject" factor. Significant effects were followed with Fisher's PLSD post hoc test with Bonferroni's correction. When homogeneity was not assumed, the Kruskal-Wallis nonparametric ANOVA was used and the Mann-Whitney $U$ test was used to determine post hoc significant of differences between groups. Fisher's exact test was used to find differences in the number of cells activated by ghrelin in the electrophysiology recordings. A value of $p<0.05$ was considered statistically significant. All data are shown as mean \pm SEM unless stated otherwise.

\section{Results}

\section{Sirt1 inhibition decreases the} excitability of NPY/Agrp neurons

Negative energy balance is supported by the activity of ARC NPY/Agrp neurons. To test whether sirtuin action affects NPY/Agrp neurons, we evaluated whether Sirt1 inhibition changes the excitability of these cells. First, we measured the membrane potential of NPY/Agrp neurons in acute slices from 4- to 7-week-old male NPY-GFP mice. After an initial stabilization of the slices in ACSF, they were incubated in EX-527 $(50 \mu \mathrm{M})$ for at least $30 \mathrm{~min}$ followed by a washout with ACSF (containing vehicle). We found that Sirt1 inhibition by EX-527 hyperpolarized the neuronal membrane potential of NPY neurons (vehicle $=-49.12 \pm 1.40 ; \mathrm{EX}-527=-51.74 \pm 1.53 ; \Delta=$ $-2.61 \pm 0.56 \mathrm{mV} ; n=4$ cells $/ 4$ mice, $\left.t_{(3)}=4.66, p<0.05\right)$ (see supplemental Fig. 1, available at www.jneurosci.org as supplemental material), while decreasing the firing rate of these cells (vehicle $=100 \pm 31 \% ;$ EX-527 $=46.6 \pm 10.8 \% ; n=4$ cells $/ 4$ mice; $\left.t_{(3)}=4.20, p<0.05\right)$, indicating a decreased excitability of these neurons.

Next, we sought to determine whether Sirtl inhibition could also impair the activation of NPY/Agrp neurons induced by ghrelin, a hormone that is elevated during negative energy balance. We found that the pretreatment of slices with EX-527 (50 $\mu \mathrm{M})$ for 30 min impairs the ghrelin-induced NPY/Agrp cell activation: in the vehicle group, 13 of 14 cells ( 7 mice) were activated by ghrelin, whereas only 1 of 4 cells ( 4 mice) were activated in the EX-527treated group ( $p<0.05$, Fisher's exact test). To understand whether our findings in slice preparation could translate to in vivo activation of NPY-GFP cells, we injected mice with EX-527 (i.c.v., $1.5 \mathrm{nmol}, 3 \mu \mathrm{l}$, according to dose-response below) $30 \mathrm{~min}$ before injecting ghrelin (i.p., $1 \mu \mathrm{g} / \mathrm{g}$ body weight). As shown in ${ }^{*} p<0.05,{ }^{* *} p<0.01$. b

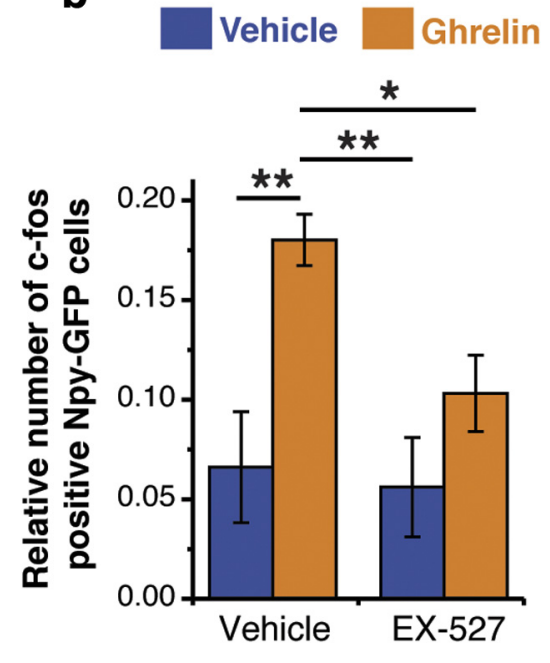

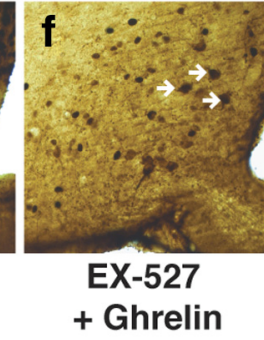

+ Ghrelin
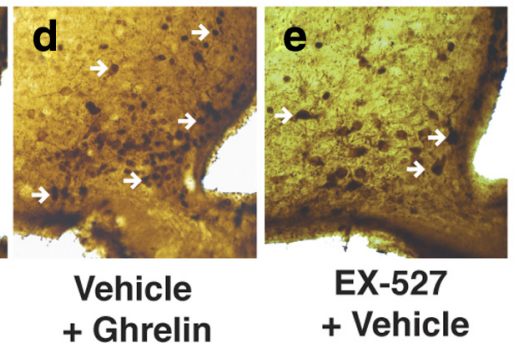

Figure 1. Sirt1 inhibition decreases ghrelin-induced c-fos expression in NPY/Agrp neurons. EX-527 (i.c.V., $1.5 \mathrm{nmol} / \mathrm{mouse}$ ), a focological inhibitor of Sirt1 (Napper et al., 2005; Pacholec et al., 2010), diminished the number of c-fos labeled NPY-GFP cells (i.p.). a, Slices from the brain highlighting the ARC (in yellow) where the NPY-GFP and c-fos cells were chemistry for GFP (DAB, brown) and c-fos (nickel DAB, black). White arrows indicate double-stained cells. $n=4-5$ mice/group.

Figure 1, ghrelin induced the activation of NPY-GFP cells as measured by the number of NPY-GFP neurons that coexpressed c-fos in their nuclei (ANOVA: $F_{(3,15)}=6.79, p<0.01 ; 179 \pm 8.33 \%$ compared to vehicle control, post hoc test $p<0.01)$. EX-527 per se did not change the ratio of c-fos/NPY-GFP cells, but it significantly attenuated the activation of NPY-GFP neurons by ghrelin $(61 \pm 16.38 \%$ compared to ghrelin control, post hoc test $p<0.05)$.

\section{Sirt1 inhibition affects synaptic input organization of hypothalamic POMC neurons}

A major efferent projection exists from the Agrp neurons to their neighboring POMC cells, and it is an inhibitory, GABAergic projection (see supplemental Fig. 2, available at www.jneurosci.org as supplemental material). Thus, next we studied the effects of EX-527 administered directly into the brain on the synaptic input organization of the POMC neurons in the ARC. Adult male wildtype mice were treated with EX-527 (i.c.v., $1.5 \mathrm{nmol}$ ) 30-60 min before the dark cycle and were killed $4 \mathrm{~h}$ later to analyze synapses on POMC neurons (by electron microscopy). We found that EX-527 blocked the recruitment of synapses onto POMC perikarya (vehicle $=63.4 \pm 9.2, \mathrm{EX}-527=38.9 \pm 6.1$ synapses per $100 \mu \mathrm{m}$ perikarya; Mann-Whitney $U=83.00, p<0.05$ ), which was predominantly the result of a decreased number of symmetric synapses (putatively inhibitory-vehicle $=43.4 \pm$ 7.8 , EX-527 $=26.8 \pm 4.3$ synapses per $100 \mu \mathrm{m}$ perikarya; MannWhitney $U=87.00, p<0.05)$ but not asymmetric synapses 
a

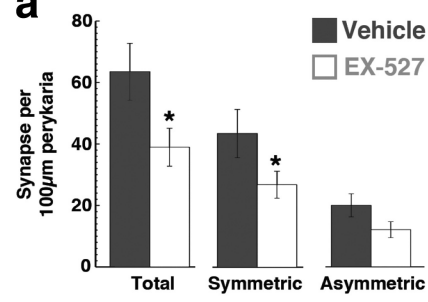

b

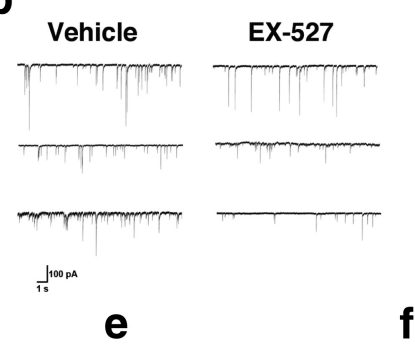

C

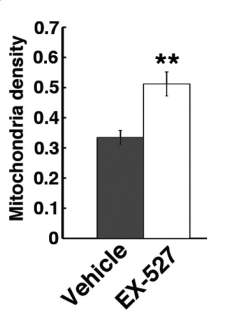

d

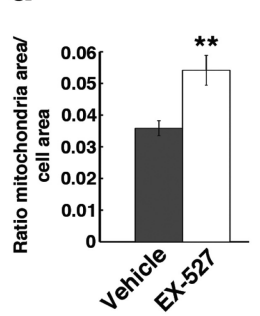

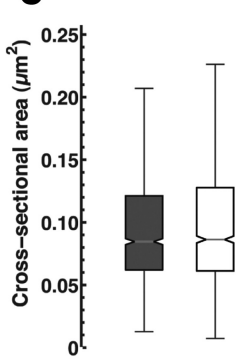

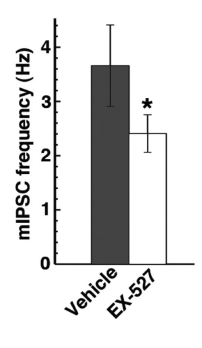

\section{$f$}

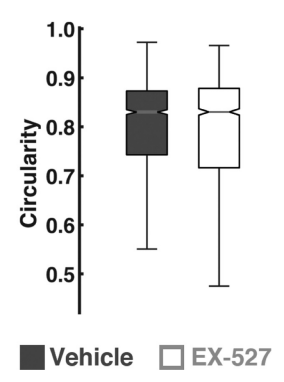

adaptations of the melanocortin system in response to negative energy balance.

\section{Brain Sirt1 inhibition decreases food intake}

Our results indicate an acute effect of Sirt1 inhibition on the organization and activity of the melanocortin system in the ARC of the hypothalamus. Because the NPY/ Agrp and POMC neurons are the core of the melanocortin system and are implicated in the regulation of food intake, we sought to determine whether the effects we found in the morphological and electrophysiological adaptations due to Sirt1 inhibition could affect food intake. To this end, we first analyzed the effects of peripheral injection of EX-527 on food intake. EX-527 (i.p., $10 \mathrm{mg} / \mathrm{kg}$ ) inhibited food intake during the dark phase (interaction time $\times$ treatment $F_{(1,8)}=9.33, p<$ 0.05 ) (Fig. 3a), a period of the circadian cycle during which orexigenic stimuli predominate in nocturnal animals. To further evaluate the acute effects of Sirt1 inhibition in the modulation of food intake, we injected EX-527 (10 mg/kg) daily into adult wild-type mice and measured food intake. In agreement with our acute data, daily peripheral injection of EX-527 given just before the dark cycle induced a (putatively excitatory—vehicle $=20.0 \pm 3.7, \mathrm{EX}-527=12.1 \pm$ 2.6 synapses per $100 \mu \mathrm{m}$ perikarya) during the first $4 \mathrm{~h}$ of the dark cycle (Fig. $2 a$; see supplemental Fig. 3 , available at www.jneurosci. org as supplemental material). An elevated number of inhibitory synapses on POMC neurons in the vehicle control group is consistent with a synaptic arrangement that promotes the suppressed activity of these satiety-signaling cells at the time of increased feeding. To confirm that Sirtl inhibition blocks the recruitment of inhibitory synapses onto POMC neurons, we also analyzed POMC-GFP cells from acute slices using whole-cell patch electrophysiological recording after incubation with Sirt1 inhibitor (EX-527, $50 \mu \mathrm{M}, 4 \mathrm{~h}$ ). In corroboration of the morphological data, we found that Sirt1 inhibition blocked the increase in the frequency of miniature IPSCs (mIPSCs) of the POMC-GFP cells $[($ vehicle $=3.6 \pm 0.7$, EX-527 $=2.4 \pm 0.3 \mathrm{~Hz} ; n=12$ cells $/ 4$ mice/group; $t_{(12)}=1.99, p<0.05$ (one-tail] (Fig. $2 b$ ).

\section{Sirt1 inhibition increases mitochondrial density in POMC neurons of the hypothalamus}

Since decreased inhibition of POMC neurons leads to increased melanocortin tone, an adaptation of the mitochondria machinery in these cells may be expected. Indeed, both mitochondrial density (vehicle $=0.33 \pm 0.02$, EX-527 $=0.51 \pm 0.04$ mitochondria per cell area; $t_{(31)}=3.34, p<0.01$ ) (Fig. $2 c$ ) and area (vehicle $=0.035 \pm 0.002$, EX-527 $=0.054 \pm 0.005 \sum$ mitochondria area per cell area; $t_{(31)}=2.96, p<0.01$ ) (Fig. $2 d$ ) were increased in POMC cells after Sirtl inhibition, an event consistent with increased activity of these cells. However, no changes in mitochondrial morphology were observed as evidenced by the distribution of the cross-sectional area of each mitochondria (Fig. 2e) and their circularity (Fig. 2f). Together, these data suggest that Sirtl contributes to the appropriate synaptic and mitochondrial

robust and consistent decrease in food intake, which persisted until the day after cessation of the treatment (treatment $F_{(1,6)}=$ $24.53, p<0.05$; time $\times$ treatment $F_{(1,6)}=2.38, p<0.05$ ) (Fig. $3 b)$. In the first $2 \mathrm{~d}, 24 \mathrm{~h}$ food intake was not significantly different. When analyzed closely, it was apparent that EX-527 reduced overnight food intake (e.g., day 1: vehicle $=4.85 \pm 0.26$, EX$\left.527=3.83 \pm 0.21 \mathrm{~g} ; t_{(6)}=3.06, p<0.05\right)$, without statistical differences in food intake during the light phase (vehicle $=$ $1.04 \pm 0.14, \mathrm{EX}-527=1.61 \pm 0.20$ ). On the remaining days (e.g., day 5), EX-527 continued to reduce overnight food intake (vehicle $\left.=5.98 \pm 0.50, \mathrm{EX}-527=4.45 \pm 0.28 ; t_{(6)}=2.67, p<0.05\right)$ without causing rebound feeding during the light cycle (vehicle $=0.59 \pm 0.17$, EX-527 $=0.54 \pm 0.07$ ).

Next, we injected EX-527 directly into the cerebral ventricles to evaluate whether the effects we found were due to inhibition of brain Sirt1 activity. Indeed, EX-527 injected directly into the cerebral ventricles also inhibited food intake in a dose-dependent manner (effect of time: $F_{(23,527)}=228.39, p<0.001$; effect of treatment: $F_{(3,527)}=4.36, p<0.05$; interaction time $\times$ treatment: $\left.F_{(69,527)}=4.28, p<0.001\right)$ (Fig. $3 c$ ). We then repeated these experiments using conditions similar to the peripherally administered EX-527 experiment (Fig. 3a), injecting the intermediate dose of EX-527 (i.c.v., $1.5 \mathrm{nmol}$ ), and found that it inhibited food intake in a manner comparable to the peripheral treatment (supplemental Fig. 5, available at www.jneurosci.org as supplemental material). To further evaluate the effects of central inhibition of Sirt1, we injected mice with EX-527 (i.c.v., $1.5 \mathrm{nmol}$ ) and simultaneously monitored food consumption, water intake and ambulatory activity (supplemental Fig. 6, available at www.jneurosci. org as supplemental material). The data obtained on food intake corroborated our previous findings, while no statistical differences in water intake were found. Finally, treatment with central 
EX-527 did not statistically change the ambulatory activity of mice (supplemental Fig. 6, available at www.jneurosci.org as supplemental material). Additionally, no overt side effects were observed by central EX-527 treatment (supplemental Table 1, available at www.jneurosci.org as supplemental material). In addition to EX-527, we also found similar results with peripheral and central administration of nicotinamide (data not shown), a natural end product of Sirt1 deacetylase activity, which inhibits Sirtl in a stoichiometric manner. Together, these data suggest that Sirt 1 coordinates neuronal circuit adaptation to negative energy balance to modulate food intake.

To further evaluate the relevance of the melanocortin system in the inhibition of Sirt1 on feeding, we analyzed the effect of the melanocortin 4-receptor antagonist, SHU9119, on EX-527's effect on food intake. SHU9119 was able to reverse the inhibition of food intake promoted by EX-527 (effect of time: $F_{(23,276)}=495.75$, $p<0.001$; effect of treatment: $F_{(2,12)}=$ $4.15, p<0.05$; interaction time $\times$ treatment: $F_{(46,276)}=2.74, p<0.001$; post hoc: vehicle $\times \mathrm{EX}-527, p<0.05$; EX-527 $\times$ EX-527+SHU9119, $p<0.05$ ) (Fig. 3d), indicating that the effect of Sirt1 inhibition on food intake uses the melanocortin receptors as a downstream effector. In the dose used in this study, we found no changes in food intake when SHU9119 was injected alone (data not shown). These data are in agreement with the results of a recent study (Cakir et al., 2009).

If Sirt1 is intrinsically important for the excitability of NPY/Agrp neurons, then signals that are known to affect food intake via these hypothalamic neurons should have an altered effect on eating when applied concomitantly with the Sirt1 inhibitor, EX-527. Ghrelin affects feeding by activation of the NPY/Agrp neurons. Thus, we injected wild-type mice with ghrelin (30 $\mu \mathrm{g} /$ mouse, i.p.) to induce food intake during the light phase of the circadian cycle, and pretreated the mice with EX-527 (i.c.v., $1.5 \mathrm{nmol}, 30-60 \mathrm{~min}$ before ghrelin). Feeding induced by the injection of ghrelin (574 $\pm 21 \%$ compared to vehicle control; Mann-Whitney $U=$ $0.00, p<0.001)$ was reversed by pretreatment with the Sirt1 inhibitor EX-527 (52 $\pm 10 \%$ inhibition compared to vehicle plus ghrelin; Mann-Whitney $U=99.50, p<0.05$ ), but did not alter normal feeding in vehicle-treated mice (Fig. $3 e$ ).

\section{The effects of brain Sirt1 inhibition are dependent upon UCP2}

Next, we evaluated whether the effects of Sirt 1 inhibition on food intake may be altered in mice with an impaired mitochondrial redox adaptation (UCP2 KO mice). The Sirt1 inhibition by any of the three doses of EX-527 used above (data
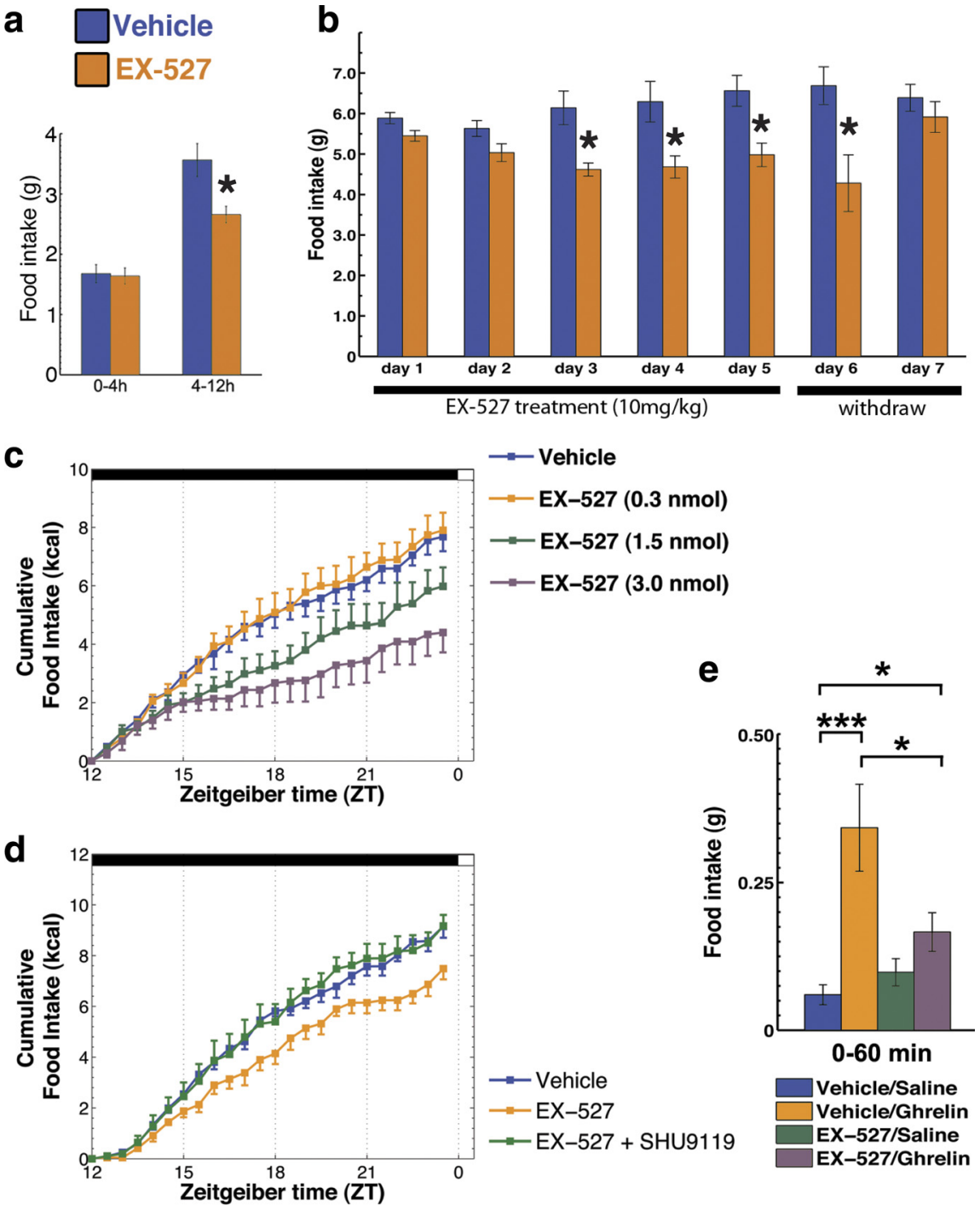

Figure 3. Inhibition of Sirt1 decreases food intake. a, Peripheral injection of a specific Sirt1 inhibitor, EX-527 (10 mg/kg), decreased the overnight food intake with no effect in the first $4 \mathrm{~h}$ (mean \pm SEM, $n=5)$. $\boldsymbol{b}$, Daily injection of EX-527 $(10 \mathrm{mg} / \mathrm{kg})$ just before the dark cycle produces a robust and consistent decrease in food intake (mean \pm SEM, $n=4$ ). c, Injection of EX-527 into he cerebral ventricles also inhibited food intake in a dose-dependent manner during the dark cycle (mean \pm SEM, $n=4-7$ ). $\boldsymbol{d}$, Sirt1 inhibition by EX-527 (i.c.v.) blunted the orexigenic effect of the gut hormone ghrelin, which depends redox adaptations in the NPY/Agrp neurons (Andrews et al., 2008) (mean \pm SEM, $n=7-13$ mice). ${ }^{*} p<0.05$, ${ }^{* *} p<0.01$, ${ }^{* * *} p<0.001$. Scale bars, $50 \mu \mathrm{m}$.

shown for i.c.v., 1.5 nmol dose) failed to show effects in UCP2 $\mathrm{KO}$ mice, while it suppressed feeding in wild-type animals (effect of time $F_{(1,31)}=71.43, p<0.001$; effect of treatment $F_{(1,31)}=9.22, p<0.01$; interaction time $\times$ treatment $\times$ genotype $F_{(1,31)}=4.80, p<0.05$ ) (Fig. 4). EX-527 also failed to block recruitment of inhibitory synapses onto POMC neurons (total: vehicle $=43.68 \pm 5.21, \mathrm{EX}-527=35.04 \pm 5.43$; symmetric: vehicle $=28.67 \pm 3.89, \mathrm{EX}-527=27.31 \pm 3.64$; asymmetric: vehicle $=15.01 \pm 2.95, \mathrm{EX}-527=7.72 \pm 2.78$ synapses per $100 \mu \mathrm{m}$ of perikarya) or increase mitochondrial density (vehicle $=0.57 \pm 0.05$, EX-527 $=0.53 \pm 0.06$ mitochondria per cell area) or area (vehicle $=0.050 \pm 0.004$, EX$527=0.049 \pm 0.005 \sum$ mitochondria area per cell area), nor did it change any of the indexes of mitochondria morphology (data not shown) in these cells during negative energy balance. 


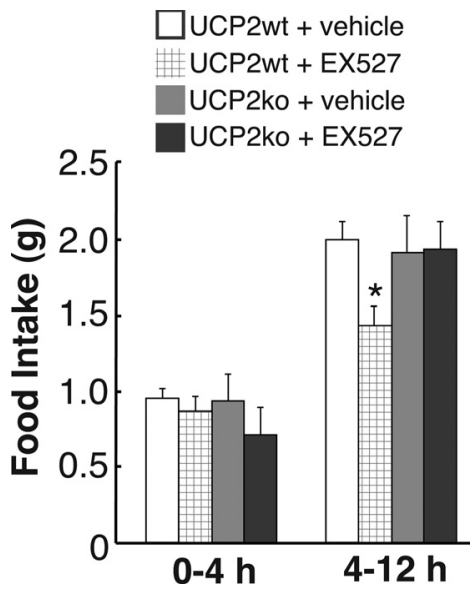

Figure 4. The effect of Sirt1 inhibition on food intake is UCP2 dependent. Inhibition of brain Sirt 1 by EX-527 (30 - 60 min before dark cycle, $1.5 \mathrm{nmol}$, i.c.v.) decreased food intake during the dark cycle in wild-type mice, but not in UCP2 KO mice (mean \pm SEM, $n=5-12$ ). ${ }^{*} p<0.05$.

\section{Sirt1 knockdown in Agrp neurons results in decreased feeding and lower body weight}

When weaned at $21 \mathrm{~d}$ of age, Agrp-Sirt1 KO mice showed no gross abnormalities, and both males and females had body weight similar to that of their control littermates (Fig. 5a). However, over time the Agrp-Sirt1 KO gained less weight than their control littermates, and at 11 weeks, both males and females were leaner than controls (Fig. 5a). Next, we analyzed the body composition of these transgenic mice using DEXA scanning to estimate lean and fat tissue weight. As presented in Figure $5 a$, females showed a more marked phenotype with reductions in both lean and fat tissue weights, while male Agrp-Sirt1 KO mice showed a consistent reduction in just lean, but not fat, mass (Fig. $5 a$ ).

Due to the more distinct phenotype of the females, we decided to characterize the metabolic parameters of these mice in metabolic chambers. Coinciding with a decreased body weight, female Agrp-Sirt1 KO mice exhibited a marked reduction in food intake compared to controls (control $=39.85 \pm 2.88, \mathrm{KO}=33.91 \pm$ $\left.0.86 \mathrm{kcal} / 72 \mathrm{~h} ; t_{(9)}=2.48, p<0.05\right)$, which was mostly due to decreased nocturnal, and not residual diurnal, food intake (data not shown). Surprisingly, over the same period of time, there was no difference in energy expenditure between control and AgrpSirt1 $\mathrm{KO}$ mice (control $=27.94 \pm 1.26, \mathrm{KO}=26.18 \pm 0.68$ $\mathrm{kcal} / 72 \mathrm{~h}$ ). Upon estimation of a relative energy balance (food intake in kcal minus energy expenditure in kcal) for these mice, we found that Agrp-Sirt1 KO animals exhibited a reduced positive energy balance in relation to their littermate controls (control $=11.91 \pm 1.83, \mathrm{KO}=7.73 \pm 0.088 \mathrm{kcal} / 72$ $\left.\mathrm{h} ; t_{(9)}=2.33, p<0.05\right)$, indicating a dysregulation in energy balance in which decreased food intake is not associated with decreased energy expenditure.

We further analyzed the daily metabolism of the Agrp-Sirt1 $\mathrm{KO}$ mice by indirect calorimetry, estimating their oxygen consumption $\left(\mathrm{VO}_{2}\right), \mathrm{VCO}_{2}$, energy expenditure, and locomotor activity. We were unable to find statistical differences in any of these parameters (Fig. $5 b-e$ ). We also estimated the respiratory quotient $\left(\mathrm{VCO}_{2} / \mathrm{VO}_{2}\right)$ and found no differences between control and Agrp-Sirt1 KO mice (data not shown).

Altogether, these data indicate that the knockdown of Sirt1 in the NPY/Agrp neurons promotes a decrease in food intake that is not accompanied by a concomitant change in energy expenditure. Moreover, these transgenic mice (Agrp-Sirt1 KO) did not display any gross alteration in any of the metabolic parameters analyzed when fed an ad libitum diet.

\section{Agrp-Sirt1 knock-out cells have diminished response to ghrelin}

Our observations highlighted an important role of Sirt1 in the NPY/Agrp neuronal regulation of overall metabolism, mainly because the KO mice showed a marked decrease in food intake and body weight gain, which was not associated with reductions in energy expenditure. In an attempt to further understand the physiology of these mutant animals, we bred our Agrp-Sirt1 KO mice with NPY-GFP mice to generate animals that expressed GFP in the NPY/Agrp cells (See material and methods and supplemental Fig. 7, available at www.jneurosci.org as supplemental material for details). In 6- to 7-week-old control-GFP and AgrpSirt1 KO-GFP mice, using whole-cell current-clamp recordings, we were able to register the membrane potential and firing rate of the NPY/Agrp neurons.

We administered ghrelin in the incubation chamber to induce NPY/Agrp cell activation and compared the effects in the control and Sirt1 KO cells. In the control-GFP cells, we were able to replicate the effect of ghrelin to increase the excitability of the NPY/Agrp neurons as measured by both a decrease in the membrane potential (vehicle $=-52.19 \pm 2.92$, ghrelin $=-41.40 \pm$ $1.14 \mathrm{mV} ; n=6$ cells $/ 6$ mice; $\left.t_{(5)}=3.26, p<0.05\right)$ and an increase in the firing rate of these cells (vehicle $=1.84 \pm 0.65$, ghrelin $=$ $5.37 \pm 1.18 \mathrm{~Hz} ; n=6$ cells $/ 6$ mice/group; $t_{(5)}=4.60, p<0.01$ ). In contrast to this, the Agrp-Sirt1 KO-GFP neurons incubated with ghrelin showed no statistical difference in either the membrane potential (vehicle $=-46.62 \pm 4.61$, ghrelin $=-40.99 \pm$ $2.63 \mathrm{mV} ; n=6$ cells $/ 6$ mice) or firing rate (vehicle $=2.55 \pm 0.62$, ghrelin $=2.46 \pm 0.49 \mathrm{~Hz} ; n=6$ cells $/ 6$ mice). Finally, $100 \%$ of the recorded neurons in the control group responded to ghrelin, while only $16 \%$ of the cells responded in the Sirt1 KO group ( $p<$ 0.01 , Fisher's exact test).

\section{Sirt1 knockdown in Agrp neurons results in impaired responses to fasting}

Because NPY/Agrp neurons play an important role in transitioning to negative energy balance, and their excitability was impaired in Agrp-Sirt1 KO mice, we postulated that challenging these mice with food deprivation could exacerbate their phenotype. Thus, we repeated the experiments in the metabolic chambers using identical conditions as before; however, we challenged the mice by fasting them $2 \mathrm{~h}$ before the dark cycle and evaluating their response during ZT 12-18 with no food available. Strikingly, the Agrp-Sirt1 KO mice showed a marked increase in ambulatory activity compared to control mice (control $=1954 \pm 65, \mathrm{KO}=$ $3115 \pm 336$ counts; $\left.t_{(9)}=2.53, p<0.05\right)$, which was concurrent with increased oxygen consumption $\left(\mathrm{VO}_{2}\right.$, control $=1552 \pm 37$, $\left.\mathrm{KO}=1783 \pm 64 \mathrm{ml} \cdot \mathrm{h}^{-1} \cdot \mathrm{kg}^{-0.75} ; t_{(9)}=2.54, p<0.05\right)$, with no differences in energy expenditure when adjusted for body weight $\left(\right.$ control $\left.=7.78 \pm 0.23, \mathrm{KO}=8.77 \pm 0.31 \mathrm{kcal} \cdot \mathrm{h}^{-1} \cdot \mathrm{kg}^{-0.75}\right)$ or cumulative energy expenditure (control $=2.49 \pm 0.04, \mathrm{KO}=$ $2.53 \pm 0.08 \mathrm{kcal} / 6 \mathrm{~h})$.

\section{Discussion}

We describe the effects of brain Sirt1 inhibition on NPY/Agrp neuronal excitability and on the synaptic and mitochondrial adaptations of POMC neurons in the ARC of the hypothalamus. Sirtl inhibition reduced NPY/Agrp neuronal firing and the synaptic input onto the POMC neurons, mainly due to a decrease in the number of inhibitory inputs on these cells. This observation is 


\begin{tabular}{|c|c|c|c|c|c|}
\hline Age & 3 weeks & 11 weeks & 3 weeks & 11 weeks & \\
\hline BW (g) & $11.22 \pm 0.30$ & $24.02 \pm 0.40$ & $10.94 \pm 0.29$ & $20.11 \pm 0.23$ & \multirow{3}{*}{$\begin{array}{l}\overline{0} \\
\text { 등 } \\
\text { 웅 }\end{array}$} \\
\hline Lean & NA & $19.68 \pm 0.39$ & NA & $16.88 \pm 0.79$ & \\
\hline Fat & NA & $3.87 \pm 0.20$ & NA & $4.15 \pm 0.30$ & \\
\hline \multirow{3}{*}{$\begin{array}{r}\text { BW (g) } \\
\text { Lean } \\
\text { Fat }\end{array}$} & $11.22 \pm 0.27$ & $22.94 \pm 0.35$ & $10.43 \pm 0.32$ & $18.77 \pm 0.46$ * & \multirow{3}{*}{ 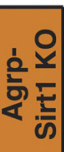 } \\
\hline & NA & $18.63 \pm 0.29^{\star}$ & NA & $15.20 \pm 0.34$ * & \\
\hline & NA & $3.60 \pm 0.14$ & NA & $3.44 \pm 0.13^{*}$ & \\
\hline
\end{tabular}

b
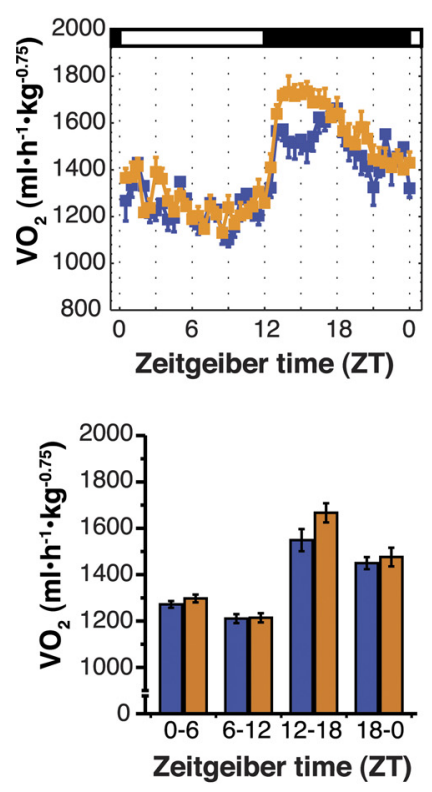

C
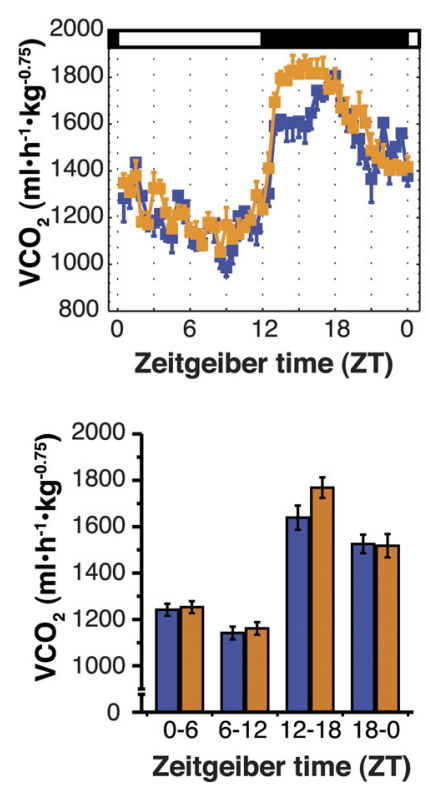

d
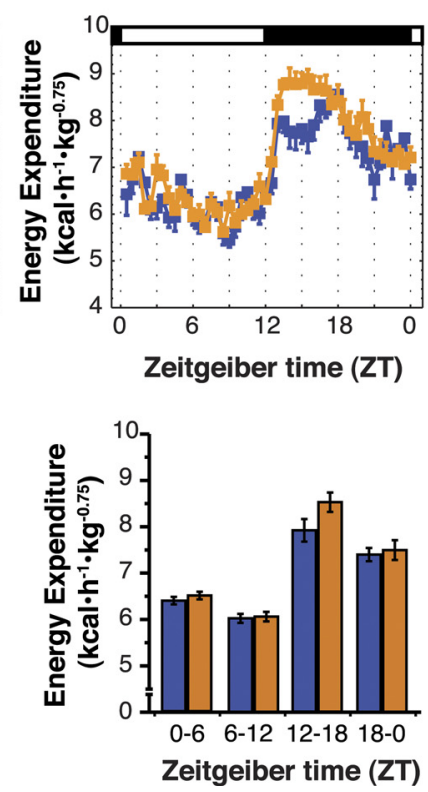

e
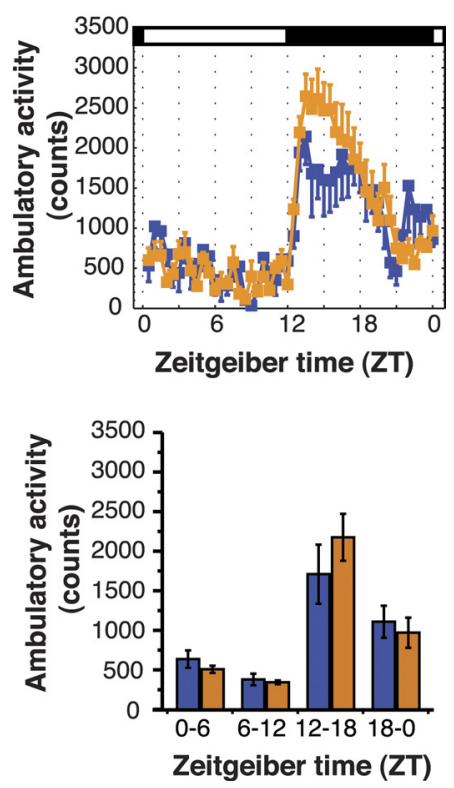

Figure 5. Agrp-Sirt1 K0 mice have decreased food intake without concomitant adaptation in energy expenditure. $\boldsymbol{a}$, Table showing the body weight at weaning and at 11 weeks old in male and female control and Agrp-Sirt1 KO mice. The KO mice gained less weight than controls, which was due mostly to decreased lean mass. Female Agrp-Sirt1 KO mice also showed a diminished fat tissue mass (mean \pm SEM, data in grams). $\boldsymbol{b}-\boldsymbol{d}$, Data from metabolic chambers showing $\mathrm{VO}_{2}, \mathrm{VCO}_{2}$, and energy expenditure, respectively, adjusted for body mass $\left(\mathrm{kg}^{-0.75}\right)$. There were no statistical differences at any of the time points analyzed. In $\boldsymbol{e}$, data on ambulatory activity of the same mice in the metabolic chambers showing no statistical differences (mean \pm SEM, $n=4-7$ ). ${ }^{*} p<0.05$.

in agreement with the finding of an increase in mitochondrial density, signifying an enhanced activity of POMC cells following brain Sirtl inhibition. We also found that Sirtl inhibition decreased food intake during the dark cycle and ghrelin-induced food intake in wild-type mice. The decrease in food intake induced by Sirt1 inhibition was reversed by a melanocortin receptor antagonist, implicating the melanocortin hypothalamic system in the behavioral effects caused by Sirtl inhibition. The behavioral and physiological effects of inhibition of Sirt1 were not observed in UCP2 KO mice, indicating a role of redox mechanisms involving UCP2 in Sirt1 effects.

\section{Evidence for specificity of brain Sirt1 pharmacological} inhibition

In the first set of experiments, we pharmacologically inhibited Sirt1 activity by EX-527, a specific Sirt1 inhibitor. Several lines of evidence support the idea that the effects seen in our experiments were due to Sirt1 inhibition and not to side effects of EX-527: (1) Sirt1 inhibition decreased food intake in a time-delayed manner only during the dark cycle and not during the light cycle (Fig. 3e); (2) Sirt1 inhibition did not decrease food intake in UCP2 KO mice (Fig. 4); (3) Sirt1 inhibition did not change symmetric synaptic and mitochondria number in UCP2 KO mice; and (4) Sirt1 inhibition had no effect on water intake and locomotor activity. Also, we have shown that EX-527 increases acetylated forms of Sirtl target proteins and that this effect is dependent on Sirt1 expression (Nie et al., 2009). Finally, we have also tested the effect of EX-527 on a cell line that resembles the phenotype of NPY/ Agrp neurons (N-39), and found an increase in the acetylated levels of Sirt1 target proteins as well (data not shown). However, while we have tested mice injected with central EX-527 acutely in several tests to exclude possible side effects of this compound on feeding, we have not tested for side effects after chronic treatment (Fig. $3 b$ ).

Participation of the melanocortin system in the effects of brain Sirt1

In mammals, the melanocortin system is central to appetite regulation (Cone, 2006). Negative energy balance, which can be induced by fasting, calorie restriction, or hormones that are active during these situations (e.g., ghrelin) (Ravussin et al., 2001; Kim et al., 2003), promotes the activity of NPY/Agrp neurons over 
POMC neurons in the ARC (Hahn et al., 1998; Chen et al., 2004). Several lines of evidence suggest the involvement of Sirt1 in the functioning of the melanocortin system in the ARC. First, Sirt1 is expressed in the ARC and its levels/activity are sensitive to negative energy balance (Ramadori et al., 2008). Recently, it was reported that Sirt1 regulates food intake in rats through the melanocortin system: inhibition of melanocortin receptor signaling by an antagonist reversed the decrease in food intake by a Sirt1 antagonist (Cakir et al., 2009). These data have been replicated in mice in the present study (Fig. $3 d$ ). A significant component of the effect of inhibition of Sirt 1 on feeding was mediated by the melanocortin system: inhibition of MC4R reversed the effect of EX-527. It is important to note, however, that the overall effect of Sirt 1 inhibition on feeding was not similar to acute interference with MC4R signaling. Both activation and inactivation of MC4R bring about acute changes in feeding (Cone, 2006). On the other hand, an acute inhibition of Sirt 1 (present data) leads to alterations in feeding in a relatively delayed manner. We further investigated the mechanisms implicated in the role of Sirt1 in the regulation of energy metabolism, and found evidence that Sirtl is important for the synaptic and mitochondrial plasticity that occurs in the melanocortin system. Specifically, pharmacological inhibition of Sirtl decreases the inhibitory but not excitatory inputs on POMC cells. The effect of Sirt1 inhibition on the synaptic plasticity of POMC neurons was consistent with the food intake data, because it relies on a mechanism that was previously proposed to have an enabling rather than an acute influence on neuronal firing (Pinto et al., 2004; Gao et al., 2007; Andrews et al., 2008). On the other hand, Sirt1 appears to be important for the maintenance of proper cellular machinery that allows the NPY/ Agrp neurons to respond to acute ghrelin administration.

\section{Participation of the redox state on the effects of Sirt1}

The effect of ghrelin on the hypothalamic melanocortin system is well established. Ghrelin promotes feeding through the activation of NPY/Agrp neurons and inhibition of POMC cells, with a consequent inhibition of MC4R in the paraventricular nucleus (PVN) (Tschöp et al., 2001, 2002; Wang et al., 2002; Chen et al., 2004; Shaw et al., 2005). We showed that ghrelin activates mitochondria respiration and proliferation in NPY/Agrp neurons that are critical for the increase in electrical activity and subsequent increases in food intake (Andrews et al., 2008). The acute feeding response to ghrelin as well as the synaptic plasticity and mitochondrial adaptation in the hypothalamus (Coppola et al., 2007; Andrews et al., 2008) and hippocampus (Dietrich et al., 2008) rely on UCP2-regulated shifts in oxidative processes. Intriguingly, oxidative conditions (in contrast to reducing conditions) have been shown to upregulate Sirt1 activity in neurons (Prozorovski et al., 2008). The present results indicate that Sirt 1 participates in the signaling involved in feeding, linking the redox state of the hypothalamic melanocortin system to the activity of Sirt 1 and its participation in the mechanisms of synaptic and mitochondrial plasticity. This assumption is reinforced by the facts that Sirt1 inhibition (1) reversed the orexigenic effects of ghrelin (Fig. 3e) and (2) did not decrease feeding UCP2 KO mice (Fig. 4).

Impaired response to food deprivation in Agrp-Sirt1 KO mice In addition to the pharmacological data, we developed a transgenic mouse model of Sirt1 deficiency in the NPY/Agrp neurons of the hypothalamus that resembles the phenotype of wild-type mice after pharmacological Sirtl inhibition in the brain. These Agrp-Sirt1 KO mice were leaner and had reduced food intake and impaired adaptation of metabolic parameters to decreased energy intake.

Sirt1 has been linked to shifts in metabolism that occur during food deprivation (Rodgers and Puigserver, 2007). During fasted states, Sirt1 maintains hepatic gluconeogenesis and fatty acid oxidation (Rodgers and Puigserver, 2007; Nie et al., 2009), and the knockdown of Sirt1 in hepatocytes diminishes $\beta$-oxidation in this tissue (Rodgers and Puigserver, 2007; Purushotham et al., 2009). Our present data are in agreement with the notion that Sirtl activity contributes to a shifting from positive to negative energy balance, because Agrp-Sirt1 KO mice showed an impaired response to food deprivation by demonstrating increased locomotor activity and oxygen consumption compared to their control littermates.

Additionally, the impaired excitability of the Agrp-Sirt1 KO NPY/Agrp cells in response to ghrelin supports the involvement of Sirt1 in shifting from positive to negative energy balance. The role of Sirt1 in modulating the transition to fatty acid metabolism during periods of negative energy balance (Rodgers and Puigserver, 2007; Purushotham et al., 2009), together with the fact that the Agrp-Sirt1 KO mice had impaired energy balance and adaptation to food deprivation, corroborates our previous data, indicating that $\beta$-oxidation contributes to NPY/Agrp neuronal activation, which regulates energy balance (Andrews et al., 2008).

\section{Comparisons between Agrp-specific Sirt1 KO and whole-body Sirt1 KO mice}

Our results contrast with those from previous studies showing that whole-body Sirt1 KO mice are hyperphagic (Chen et al., 2005; Pani et al., 2006). However, the data from studies using Sirt1 KO mice are difficult to interpret, because these mice have profound developmental problems, and only a small number of pups reach adulthood (Cheng et al., 2003; McBurney et al., 2003). Once the knock-out mice reach adulthood, they gain $\sim 60 \%$ more body weight than their littermates (Chen et al., 2005). Thus, the hyperphagic behavior of the Sirt $1 \mathrm{KO}$ mice is likely caused by complex compensatory developmental mechanisms that have little to do with Sirt1 normal physiological mechanisms in the adult brain. In our studies, we used an acute inhibition of or chronic knockdown of Sirt1 specifically in the Agrp neurons (Agrp-Sirt1 $\mathrm{KO}$ mice). In contrast to the whole-body Sirt1 KO mice, the Agrp-Sirt1 KO mice were born in Mendelian rates, had no gross developmental problems compared to their littermates, and demonstrated decreased feeding.

\section{Concluding remarks}

Our data on hypothalamic neurobiological events indicate that Sirtl activation in NPY/Agrp neurons is a determinant of their excitability, which consequently is important for appropriate shifts in behavioral, autonomic, and endocrine processes to occur for adaptation to negative energy balance. These findings reveal a novel mechanism by which the selective activation of Sirt 1 within the NPY/Agrp neurons promotes negative energy balance that is characteristic of calorie restriction, which promotes a longer, healthier lifespan.

\section{References}

Andrews ZB, Liu ZW, Wallingford N, Erion DM, Borok E, Friedman JM, Tschöp MH, Shanabrough M, Cline G, Shulman GI, Coppola A, Gao XB, 
Horvath TL, Diano S (2008) UCP2 mediates ghrelin's action on NPY/ AgRP neurons by lowering free radicals. Nature 454:846-851.

Brachmann CB, Sherman JM, Devine SE, Cameron EE, Pillus L, Boeke JD (1995) The SIR2 gene family, conserved from bacteria to humans, functions in silencing, cell cycle progression, and chromosome stability. Genes Dev 9:2888-2902.

Cakir I, Perello M, Lansari O, Messier NJ, Vaslet CA, Nillni EA (2009) Hypothalamic Sirt1 regulates food intake in a rodent model system. PLoS One 4:e8322.

Chen D, Guarente L (2007) SIR2: a potential target for calorie restriction mimetics. Trends Mol Med 13:64-71.

Chen D, Steele AD, Lindquist S, Guarente L (2005) Increase in activity during calorie restriction requires Sirt1. Science 310:1641.

Chen D, Bruno J, Easlon E, Lin SJ, Cheng HL, Alt FW, Guarente L (2008) Tissue-specific regulation of SIRT1 by calorie restriction. Genes Dev 22:1753-1757.

Chen HY, Trumbauer ME, Chen AS, Weingarth DT, Adams JR, Frazier EG, Shen Z, Marsh DJ, Feighner SD, Guan XM, Ye Z, Nargund RP, Smith RG, Van der Ploeg LH, Howard AD, MacNeil DJ, Qian S (2004) Orexigenic action of peripheral ghrelin is mediated by neuropeptide $\mathrm{Y}$ and agoutirelated protein. Endocrinology 145:2607-2612.

Cheng HL, Mostoslavsky R, Saito S, Manis JP, Gu Y, Patel P, Bronson R, Appella E, Alt FW, Chua KF (2003) Developmental defects and p53 hyperacetylation in Sir2 homolog (SIRT1)-deficient mice. Proc Natl Acad Sci U S A 100:10794-10799.

Cohen HY, Miller C, Bitterman KJ, Wall NR, Hekking B, Kessler B, Howitz KT, Gorospe M, de Cabo R, Sinclair DA (2004) Calorie restriction promotes mammalian cell survival by inducing the SIRT1 deacetylase. Science 305:390-392.

Cone RD (2006) Studies on the physiological functions of the melanocortin system. Endocr Rev 27:736-749.

Coppola A, Liu ZW, Andrews ZB, Paradis E, Roy MC, Friedman JM, Ricquier D, Richard D, Horvath TL, Gao XB, Diano S (2007) A central thermogenic-like mechanism in feeding regulation: an interplay between arcuate nucleus T3 and UCP2. Cell Metab 5:21-33.

Cowley MA, Smart JL, Rubinstein M, Cerdán MG, Diano S, Horvath TL, Cone RD, Low MJ (2001) Leptin activates anorexigenic POMC neurons through a neural network in the arcuate nucleus. Nature 411:480-484.

Dietrich MO, Andrews ZB, Horvath TL (2008) Exercise-induced synaptogenesis in the hippocampus is dependent on UCP2-regulated mitochondrial adaptation. J Neurosci 28:10766-10771.

Gao Q, Mezei G, Nie Y, Rao Y, Choi CS, Bechmann I, Leranth C, ToranAllerand D, Priest CA, Roberts JL, Gao XB, Mobbs C, Shulman GI, Diano S, Horvath TL (2007) Anorectic estrogen mimics leptin's effect on the rewiring of melanocortin cells and Stat 3 signaling in obese animals. Nat Med 13:89-94.

Gropp E, Shanabrough M, Borok E, Xu AW, Janoschek R, Buch T, Plum L, Balthasar N, Hampel B, Waisman A, Barsh GS, Horvath TL, Brüning JC (2005) Agouti-related peptide-expressing neurons are mandatory for feeding. Nat Neurosci 8:1289-1291.

Hahn TM, Breininger JF, Baskin DG, Schwartz MW (1998) Coexpression of Agrp and NPY in fasting-activated hypothalamic neurons. Nat Neurosci 1:271-272.

Horvath TL, Naftolin F, Kalra SP, Leranth C (1992) Neuropeptide-Y innervation of beta-endorphin-containing cells in the rat mediobasal hypothalamus: a light and electron microscopic double immunostaining analysis. Endocrinology 131:2461-2467.

Huhtiniemi T, Wittekindt C, Laitinen T, Leppänen J, Salminen A, Poso A, Lahtela-Kakkonen M (2006) Comparative and pharmacophore model for deacetylase SIRT1. J Comput Aided Mol Des 20:589-599.

Kaeberlein M, McVey M, Guarente L (1999) The SIR2/3/4 complex and SIR2 alone promote longevity in Saccharomyces cerevisiae by two different mechanisms. Genes Dev 13:2570-2580.

Kaelin CB, Xu AW, Lu XY, Barsh GS (2004) Transcriptional regulation of agouti-related protein (Agrp) in transgenic mice. Endocrinology 145: 5798-5806.

Kim MS, Yoon CY, Park KH, Shin CS, Park KS, Kim SY, Cho BY, Lee HK (2003) Changes in ghrelin and ghrelin receptor expression according to feeding status. Neuroreport 14:1317-1320.

Kitamura T, Feng Y, Kitamura YI, Chua SC Jr, Xu AW, Barsh GS, Rossetti L, Accili D (2006) Forkhead protein FoxO1 mediates Agrp-dependent effects of leptin on food intake. Nat Med 12:534-540.
Könner AC, Janoschek R, Plum L, Jordan SD, Rother E, Ma X, Xu C, Enriori P, Hampel B, Barsh GS, Kahn CR, Cowley MA, Ashcroft FM, Brüning JC (2007) Insulin action in AgRP-expressing neurons is required for suppression of hepatic glucose production. Cell Metab 5:438-449.

Li H, Rajendran GK, Liu N, Ware C, Rubin BP, Gu Y (2007) SirT1 modulates the estrogen-insulin-like growth factor-1 signaling for postnatal development of mammary gland in mice. Breast Cancer Res 9:R1.

Lin SJ, Defossez PA, Guarente L (2000) Requirement of NAD and SIR2 for life-span extension by calorie restriction in Saccharomyces cerevisiae. Science 289:2126-2128.

Liu Y, Dentin R, Chen D, Hedrick S, Ravnskjaer K, Schenk S, Milne J, Meyers DJ, Cole P, Yates J 3rd, Olefsky J, Guarente L, Montminy M (2008) A fasting inducible switch modulates gluconeogenesis via activator/coactivator exchange. Nature 456:269-273.

Luquet S, Perez FA, Hnasko TS, Palmiter RD (2005) NPY/AgRP neurons are essential for feeding in adult mice but can be ablated in neonates. Science 310:683-685.

McBurney MW, Yang X, Jardine K, Hixon M, Boekelheide K, Webb JR, Lansdorp PM, Lemieux M (2003) The mammalian SIR2alpha protein has a role in embryogenesis and gametogenesis. Mol Cell Biol 23:38-54.

Napper AD, Hixon J, McDonagh T, Keavey K, Pons JF, Barker J, Yau WT, Amouzegh P, Flegg A, Hamelin E, Thomas RJ, Kates M, Jones S, Navia MA, Saunders JO, DiStefano PS, Curtis R (2005) Discovery of indoles as potent and selective inhibitors of the deacetylase SIRT1. J Med Chem 48:8045-8054.

Nie Y, Erion DM, Yuan Z, Dietrich M, Shulman GI, Horvath TL, Gao Q (2009) STAT3 inhibition of gluconeogenesis is downregulated by SirT1. Nat Cell Biol 11:492-500.

Pacholec M, Bleasdale JE, Chrunyk B, Cunningham D, Flynn D, Garofalo RS, Griffith D, Griffor M, Loulakis P, Pabst B, Qiu X, Stockman B, Thanabal V, Varghese A, Ward J, Withka J, Ahn K (2010) SRT1720, SRT2183, SRT1460, and resveratrol are not direct activators of SIRT1. J Biol Chem 285:8340-8351.

Pani G, Fusco S, Galeotti T (2006) Smaller, hungrier mice. Science 311: 1553-1554; author reply 1553-1554.

Paxinos G, Franklin KBJ (2001) The mouse brain in stereotaxic coordinates, Ed 2. San Diego: Academic.

Pierce AA, Xu AW (2010) De novo neurogenesis in adult hypothalamus as a compensatory mechanism to regulate energy balance. J Neurosci 30:723-730.

Pinto S, Roseberry AG, Liu H, Diano S, Shanabrough M, Cai X, Friedman JM, Horvath TL (2004) Rapid rewiring of arcuate nucleus feeding circuits by leptin. Science 304:110-115.

Prozorovski T, Schulze-Topphoff U, Glumm R, Baumgart J, Schröter F, Ninnemann O, Siegert E, Bendix I, Brüstle O, Nitsch R, Zipp F, Aktas O (2008) Sirt1 contributes critically to the redox-dependent fate of neural progenitors. Nat Cell Biol 10:385-394.

Purushotham A, Schug TT, Xu Q, Surapureddi S, Guo X, Li X (2009) Hepatocyte-specific deletion of SIRT1 alters fatty acid metabolism and results in hepatic steatosis and inflammation. Cell Metab 9:327-338.

Ramadori G, Lee CE, Bookout AL, Lee S, Williams KW, Anderson J, Elmquist JK, Coppari R (2008) Brain SIRT1: anatomical distribution and regulation by energy availability. J Neurosci 28:9989-9996.

Ravussin E, Tschöp M, Morales S, Bouchard C, Heiman ML (2001) Plasma ghrelin concentration and energy balance: overfeeding and negative energy balance studies in twins. J Clin Endocrinol Metab 86:4547-4551.

Rodgers JT, Puigserver P (2007) Fasting-dependent glucose and lipid metabolic response through hepatic sirtuin 1. Proc Natl Acad Sci U S A 104:12861-12866.

Rogina B, Helfand SL (2004) Sir2 mediates longevity in the fly through a pathway related to calorie restriction. Proc Natl Acad Sci U S A 101: $15998-16003$.

Shaw AM, Irani BG, Moore MC, Haskell-Luevano C, Millard WJ (2005) Ghrelin-induced food intake and growth hormone secretion are altered in melanocortin 3 and 4 receptor knockout mice. Peptides 26:1720-1727.

Solomon JM, Pasupuleti R, Xu L, McDonagh T, Curtis R, DiStefano PS, Huber LJ (2006) Inhibition of SIRT1 catalytic activity increases p53 acetylation but does not alter cell survival following DNA damage. Mol Cell Biol 26:28-38.

Soriano P (1999) Generalized lacZ expression with the ROSA26 Cre reporter strain. Nat Genet 21:70-71. 
Tissenbaum HA, Guarente L (2001) Increased dosage of a sir-2 gene extends lifespan in Caenorhabditis elegans. Nature 410:227-230.

Tschöp M, Wawarta R, Riepl RL, Friedrich S, Bidlingmaier M, Landgraf R, Folwaczny C (2001) Post-prandial decrease of circulating human ghrelin levels. J Endocrinol Invest 24:RC19-21.

Tschöp M, Statnick MA, Suter TM, Heiman ML (2002) GH-releasing peptide-2 increases fat mass in mice lacking NPY: indication for a crucial mediating role of hypothalamic agouti-related protein. Endocrinology 143:558-568.

Wang L, Saint-Pierre DH, Taché Y (2002) Peripheral ghrelin selectively increases Fos expression in neuropeptide Y-synthesizing neurons in mouse hypothalamic arcuate nucleus. Neurosci Lett 325:47-51.

Wu Q, Boyle MP, Palmiter RD (2009) Loss of GABAergic signaling by AgRP neurons to the parabrachial nucleus leads to starvation. Cell 137: 1225-1234.

Xu AW, Kaelin CB, Takeda K, Akira S, Schwartz MW, Barsh GS (2005a) PI3K integrates the action of insulin and leptin on hypothalamic neurons. J Clin Invest 115:951-958.

Xu AW, Kaelin CB, Morton GJ, Ogimoto K, Stanhope K, Graham J, Baskin DG, Havel P, Schwartz MW, Barsh GS (2005b) Effects of hypothalamic neurodegeneration on energy balance. PLoS Biol 3:e415.

Zhang CY, Baffy G, Perret P, Krauss S, Peroni O, Grujic D, Hagen T, VidalPuig AJ, Boss O, Kim YB, Zheng XX, Wheeler MB, Shulman GI, Chan CB, Lowell BB (2001) Uncoupling protein-2 negatively regulates insulin secretion and is a major link between obesity, beta cell dysfunction, and type 2 diabetes. Cell 105:745-755. 